\title{
Uji Beberapa Dosis Minyak Daun Kemangi Ocimum basilicum Linnaeus sebagai Atraktan terhadap Bactrocera spp. pada Tanaman Cabai
}

\author{
The Experiment of Dosage Basil Leaf Oil Ocimum basilicum Linnaeus as an Attractant against \\ Bactrocera sp. on Chili Plant \\ Fitriah Sucindra Mefta ${ }^{1)^{*}}$, Hafiz Fauzana ${ }^{2)}$ \\ 1) Jurusan Agroteknologi, Fakultas Pertanian Universitas Riau \\ 2)Jurusan Agroteknologi, Fakultas Pertanian Universitas Riau \\ E-mail:mifthasucin@gmail.com \\ Diterima: 14 Februari 2021 Disetujui: 04 Juni 2021 Dipublikasi: 30 Juni 2021
}

\begin{abstract}
Fruit flies, Bactrocera spp., are the primary pests on chili plants (Capsicum annuum Linnaeus). A safe and effective control uses traps combined with an attractant from basil leaf oil (Ocimum basilicum Linnaeus). This study aimed to determine the attractiveness of basil leaf oil against fruit flies at several different doses. This research was carried out in Organic Chemistry Laboratory STIFARM Padang, in Tabek Patah Tanah Datar area West Sumatra, and in the Pest Disease Observation and Development of Biological Agents Laboratory, Bukittinggi, West Sumatra, from June to August 2020. The treatment was in the form of different doses of basil leaf oil, which was $0,5 \mathrm{ml}$ per trap, $1.0 \mathrm{ml}$ per trap, $1.5 \mathrm{ml}$ per trap, $2.0 \mathrm{ml}$ per trap, and $2.5 \mathrm{ml}$ per trap. The experiment used a completely randomized design with five treatments and three replications. This study found two species of fruit flies around chili plants, namely Bactrocera papayae and Bactrocera carambolae, which were dominated by male B. papayae. The traps containing $1.5 \mathrm{ml}$ of basil leaf oil attracted the most fruit flies. Temperature and humidity significantly affect the abundance of individual fruit flies.
\end{abstract}

Keywords: Attractant, basil leaf oil, Bactrocera spp., Capsicum annuum, doses, Ocimum basilicum

PENDAHULUAN

Cabai (Capsicum annuum Linnaeus) merupakan tanaman yang mempunyai nilai ekonomis sangat tinggi di Indonesia. Selain bisa menggugah rasa, cabai juga mengandung vitamin, mineral, zat besi, posfor, dan niasin. Saat ini, buah cabai sudah dijadikan pula sebagai bahan baku industri makanan (Syukur, 2018). Khusus untuk Provinsi Sumatera Barat, cabai sudah menjadi bagian tidak terpisahkan dalam setiap menu makanan, sehingga turun naik produksi dapat mempengaruhi kondisi sehari-hari masyarakat.

Daerah penghasil cabai tertinggi di Indonesia saat ini adalah Jawa Barat (274,038 ton), Jawa Tengah (171,796 ton), Sumatera Utara (155,836 ton), Sumatera Barat $(105,061$ ton), Jawa Timur $(91,966$ ton), Aceh (68,153 ton), Lampung $(45,380$ ton), Sumatera Selatan (41,814 ton), Bengkulu (39,794 ton), dan Jambi $(38,003$ ton) (Badan Pusat Statistik Indonesia, 2019). 
Badan Pusat Statistik Indonesia (2019) melaporkan terjadinya peningkatan produksi cabai setiap tahunnya. Tahun 2016, 2017, 2018, dan 2019 produksi cabai per tahun di Sumatera Barat masing - masing yaitu 68,224 ton, 95,489 ton, 106,061 ton, dan 139,994 ton.

Salah satu hama utama yang menganggu produksi tanaman cabai secara kualitas dan kuantitas adalah lalat buah Bactrocera spp. (Arief, 2009). Larva lalat buah menyerang tanaman cabai dengan cara memakan daging buah, buah mengalami kerusakan dan cepat busuk (Hasyim et al., 2020). Curah hujan, suhu, kelembapan, dan sinar matahari merupakan faktor lingkungan yang dapat mempengaruhi perkembangan hidup Bactrocera sp. (Susanto et al., 2017). Muryati et al. (2007) melaporkan beberapa spesies lalat buah yang ditemukan di Sumatera Barat yaitu Bactrocera carambolae, Bactrocera papayae, Bactrocera umbrosa, Bactrocera cucurbitae, Bactrocera tau, dan Bactrocera albistrigata. Serangan lalat buah ini dapat menyebabkan kehilangan hasil mencapai 94,4\% (Arief, 2009). Sementara itu menurut Septiawati (2021), intensitas serangan lalat buah di Kota Padang Sumatera Barat mencapai 52,3\%.

Berbagai upaya pengendalian yang dilakukan untuk mengurangi serangan lalat buah antara lain pengendalian secara fisik, mekanik, kultur teknis, biologi, dan sintetik. Arif_(2015) menyatakan, insektisida sintetik dapat menimbulkan beberapa masalah seperti tidak dapat terurai, mematikan biota air, resistensi hama, munculnya hama sekunder, terbunuhnya musuh alami, dan keracunan pada manusia.

Salah satu cara pengendalian yang paling efektif dan ramah lingkungan adalah penggunaan alat perangkap yang diberi senyawa penarik atau atraktan. Atraktan dilaporkan efektif dalam menarik kehadiran lalat buah, tidak meninggalkan residu pada buah sehingga ramah untuk lingkungan, dan tidak menyebabkan pencemaran lingkungan (Anugraheni, 2018). Metil eugenol adalah salah satu senyawa yang bersifat atraktan yang mampu memikat lalat buah jantan dan betina (Kardinan, 2019). Beberapa jenis tanaman penghasil senyawa metil eugenol yaitu bunga cengkeh (Syzygium maromaticum), serai wangi (Cymbopogon citratus), nilam (Pogostemon cablin), selasih (Ocimum sanctum), dan kemangi (Ocimum basilicum) (Ketaren, 1985; Trihutanti, 2018; Kardinan, 2019)).

Kemangi merupakan tanaman dari genus Ocimum yang beraroma seperti minyak cengkeh dan mampu menghasilkan minyak atsiri. Salbiah et al. (2013) telah menguji minyak atsiri dari tanaman jeringau, seledri, serai wangi, dan kemangi. Minyak atsiri terbaik untuk dijadikan atraktan yaitu tanaman kemangi, dimana rata-rata lalat buah jantan yang terperangkap paling tinggi yaitu sebanyak 26,83 ekor dengan masa aktif atraktan selama 4,66 hari. Yuniastuti (2015) melaporkan 1,5 $\mathrm{ml}$ minyak selasih yang diletakkan dalam perangkap efektif memikat lalat buah pada tanaman sayur dan buah. Penelitian ini bertujuan untuk mengetahui pengaruh perbedaan dosis minyak daun kemangi sebagai atraktan terhadap terhadap lalat buah Bactrocera sp yang menyerang tanaman cabai.

\section{METODOLOGI}

Penelitian ini dilaksanakan di tiga lokasi. Pembuatan minyak daun kemangi dilaksanakan di Laboratorium Kimia Organik Sekolah Tinggi Ilmu Farmasi Padang, pema- 
sangan perangkap dilaksanakan di lahan Tabek Patah Tanah Datar Sumatera Barat dan identifikasi lalat buah dilaksanakan di Laboratorium Pengamatan Hama Penyakit dan Pengembangan Agens Hayati Bukittinggi Sumatera Barat. Penelitian ini dilaksanakan selama tiga bulan yaitu pada bulan Juni sampai Agustus 2020.

\section{Metode}

Penelitian ini merupakan penelitian lapangan dengan menggunakan Rancangan Acak Lengkap (RAL) dengan lima perlakuan dan tiga ulangan sehingga diperoleh 15 unit percobaan. Perlakuan berupa perbedaan dosis minyak daun kemangi per perangkap: $0,5 \mathrm{ml}, 1,0 \mathrm{ml}, 1,5 \mathrm{ml}, 2,0 \mathrm{ml}$, dan 2,5 ml.

\section{Deskripsi Lokasi Penelitian}

Agroekosistem tanaman cabai yang diamati yaitu pada ketinggian $1.170 \mathrm{~m}$ dpl di daerah Tanjung Alam, Tanjung Baru, Tanah Datar, Sumatera Barat. Komponen biotik yang diamati yaitu tanaman cabai sebagai tanaman pokok dan tanaman disekitarnya adalah daun bawang, terung, serta jagung. Daun bawang yang ditanam hanya satu jalur di samping bedengan cabai. Penanaman terung di samping bedengan cabai sebanyak 2 bedengan saja, sedangkan penanaman jagung di bagian pinggir lahan (Gambar 1). Tanaman daun bawang dan jagung bukan inang lalat buah, akan tetapi tanaman terung merupakan tanaman inang dari lalat buah. Kondisi lahan kurang terawat, seperti tidak ada pembersihan gulma, sedangkan buah busuk yang terserang dibiarkan berserakan disekitar lahan.

Tanaman cabai yang diamati yaitu tanaman cabai varietas kopay yang sudah ditanam oleh petani setempat di daerah Tabek Patah Tanah Datar Sumatera Barat dengan luas lahan 0,16 ha. Tanaman cabai tersebut memiliki jarak tanam $75 \times 75 \mathrm{~cm}$ dan dalam satu bedengan terdapat 40 populasi. Tanaman cabai dalam kondisi sedang berbuah, berumur tiga bulan setelah tanam.
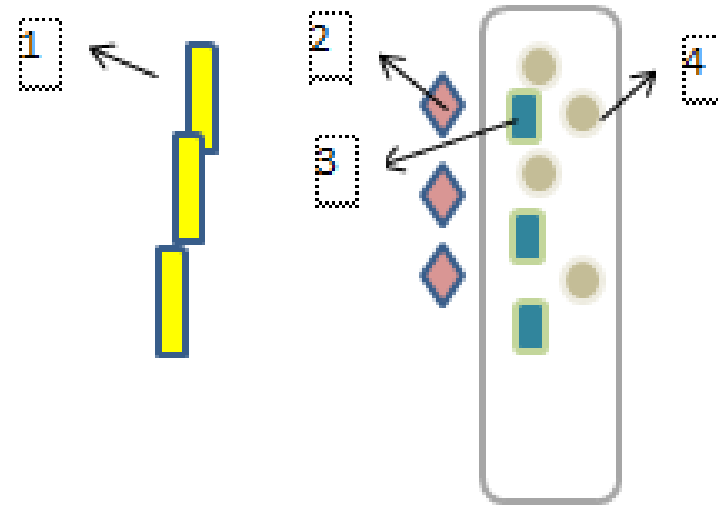

Gambar 1. Deskripsi lokasi penelitian

\section{Pelaksanaan}

\section{Pembuatan ekstrak daun kemangi}

Sekitar 5 kg daun kemangi varietas tidore yang telah berumur empat bulan dicuci menggunakan air mengalir, kemudian dikering-anginkan selama dua hari. Daun kemangi yang telah dikering-anginkan dilakukan penimbangan dengan berat kering 3,5 kg. Tahap selanjutnya daun kemangi dilakukan proses destilasi. Destilasi daun 
kemangi diperlukan 13 kali pengerjaan untuk menghasilkan $22,5 \mathrm{ml}$. Untuk satu kali pengerjaan dibutuhkan $250 \mathrm{~g}$ dari $3,5 \mathrm{~kg}$ berat kering daun kemangi. Daun dimasukkan ke dalam panci penyulingan. Daun kemangi didestilasi selama empat jam untuk memperoleh minyak atsiri 1,8 ml. Hasil penyulingan dimasukkan ke dalam dua botol kaca berukuran $10 \mathrm{ml}$ dan satu botol kaca berukuran $5 \mathrm{ml}$ lalu ditutup rapat.

\section{Pembuatan perangkap}

Perangkap dibuat dengan menggunakan botol minuman mineral berukuran 600 $\mathrm{ml}$. botol dipotong menggunakan cutter.
Tutup botol aqua dilepas dan mulut botol diikatkan pada kawat yang telah disediakan. Kapas diikatkan pada kawat sebagai tempat pemberian minyak daun kemangi. Minyak daun kemangi diteteskan sesuai perlakuan pada kapas yang telah diikatkan pada kawat. Botol diletakkan kembali dengan arah yang terbalik sebagai tempat masuknya lalat buah dan direkatkan dengan menggunakan alat perekat. Tali rafia sepanjang $10 \mathrm{~cm}$ diikatkan ke botol dan digantung pada ajir yang telah disediakan dibagian pinggir lahan dengan ketinggian $110 \mathrm{~cm}$. Dibutuhkan 15 buah perangkap untuk satu lokasi penelitian (Gambar 2).

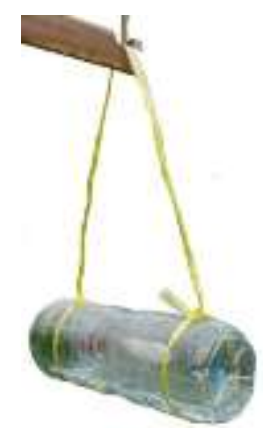

a)

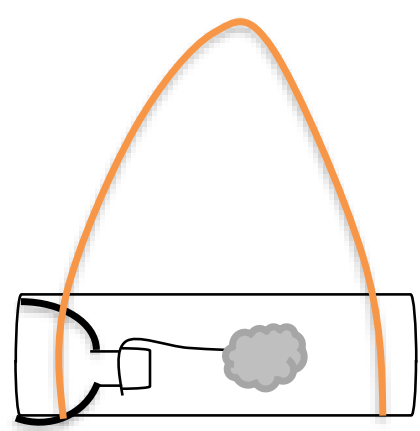

b)

Gambar 2. Bentuk perangkap lalat buah a) Foto asli, b) desain

Perangkap diletakkan dengan menggunakan metode systematic sampling. Pola pemasangan perangkap lalat buah menggunakan pola zig-zag dimulai setelah dua baris tepi dari tanaman cabai. Pemasangan perangkap dilakukan pada pagi hari jam 06.00 WIB. Lalat buah yang terperangkap diambil setelah 4 jam pemasangan perangkap (periode aktifnya lalat buah pada pagi hari pukul 06.00-10.00 WIB) selama tujuh hari (Gambar 3).

\section{Parameter Pengamatan}

\section{Spesies lalat buah yang ditemukan}

Semua lalat buah yang terperangkap diidentifikasi dengan melihat perbedaan ciri morfologi kemudian dibandingkan dengn buku pedoman identifikasi lalat buah (Suputa et al., 2006), buku taksonomi dan bioekologi lalat buah penting di Indonesia (Siwi et al., 2006), dan buku teknologi pengendalian hama lalat buah (Hasyim et al., 2020).

\section{Kelimpahan individu}

Penghitungan kelimpahan individu lalat buah yang ditemukan dilakukan per spesies pada masing-masing perangkap sesuai perlakuan. Rumus yang digunakan adalah:

$\mathrm{KI}=\frac{\text { Jumlah individu spesies i yang ditemukan }}{\text { Jumlah perangkap yang dipasang }}$

Keterangan:

$\mathrm{KI}=$ Kelimpahan individu 


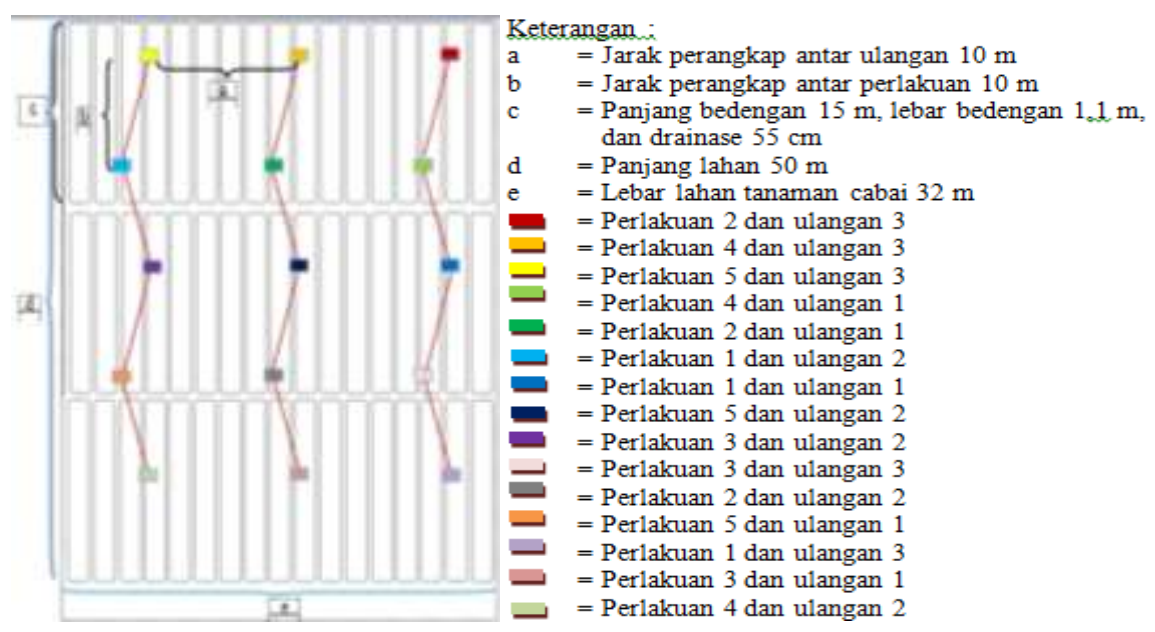

Gambar 3. Denah pemasangan perangkap

\section{Sex ratio}

Sex ratio adalah perbandingan jumlah individu antara lalat buah jantan dan betina, yang dapat diketahui melalui perbedaan ukuran dan morfologi. Imago jantan berukuran lebih kecil dari betina, ujung posterior abdomen bulat dan memendek, sedangkan ujung posterior abdomen betina melengkung ke bawah menuju titik lancip bagian tengah dibelakang (memiliki ovipositor) (Hotimah et al., 2017). Sex ratio dihitung dengan menggunakan rumus:

$\mathrm{SR}=\frac{\sum \mathrm{J}}{\sum \mathrm{B}}$

Keterangan:

SR : Sex ratio

$\sum J \quad$ : Jumlah imago jantan

$\sum B \quad$ : Jumlah imago betina

\section{Suhu dan kelembaban}

Suhu dan kelembaban harian diukur menggunakan termohigrometer digital. Pengukuran suhu dan kelembaban dilakukan tiga kali sehari selama satu minggu pengamatan, yaitu pada pukul 07.00 wib, 13.00 wib, dan 17.00 wib.

\section{Analisis data}

Data spesies lalat buah ditampilkan secara deskriptif dalam bentuk tabel. Data kelimpahan individu dan sex ratio dihitung manual dan data agroekosistem dianalisis menggunakan analisis deskriptif. Hasil pengamatan kelimpahan individu yang diperoleh diuji menggunakan analisis sidik ragam (metode SPSS Statistics 24) dengan rumus sebagai berikut:

$$
Y i j=\mu+\tau i+€ i j
$$

Keterangan:

Yij : Nilai pengamatan pada perlakuan dosis minyak kemangi ke-i dan ulangan ke-j

$\mu$ : Rataan umum

זi : Pengaruh perlakuan dosis minyak kemangi ke-i

$€ \mathrm{ij}$ : Galat percobaan perlakuan dosis minyak kemangi ke-i dan ulangan ke-j

Pengujian lanjut pengamatan dengan menggunakan uji beda nyata terkecil atau BNT taraf 5\% dan ditransformasi menggunakan aplikasi SPSS Statistics 24.

\section{HASIL}

\section{Spesies Lalat Buah yang Ditemukan}

Berdasarkan pengamatan yang dilakukan terhadap 350 ekor lalat buah yang dikoleksi, ditemukan dua spesies lalat buah yaitu Bactrocera papayae Drew and Hancock dan Bactrocera carambolae Drew and Hancock (Tabel 1). 
Tabel 1. Hasil identifikasi spesies lalat buah berdasarkan morfologi, dan dibandingkan dengan gambar rujukan dari Suputa et al. (2006)

No Gambar asli Gambar rujukan Ciri-Ciri

1 B. papayae

a. Caput

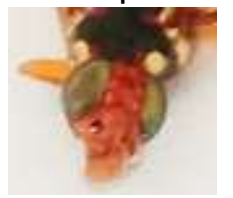

b. Toraks

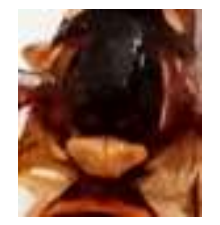

Toraks

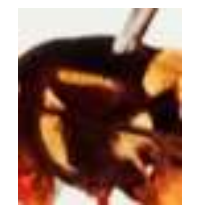

c. Abdomen

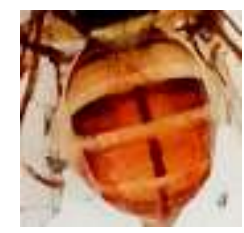

d. Sayap

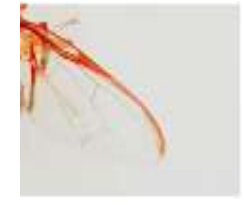

e. Tibia kaki

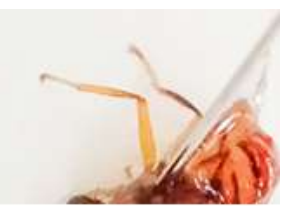

2 B. carambolae

a. Caput

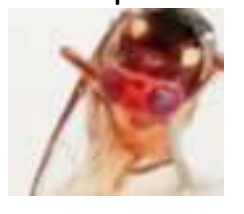

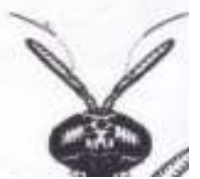
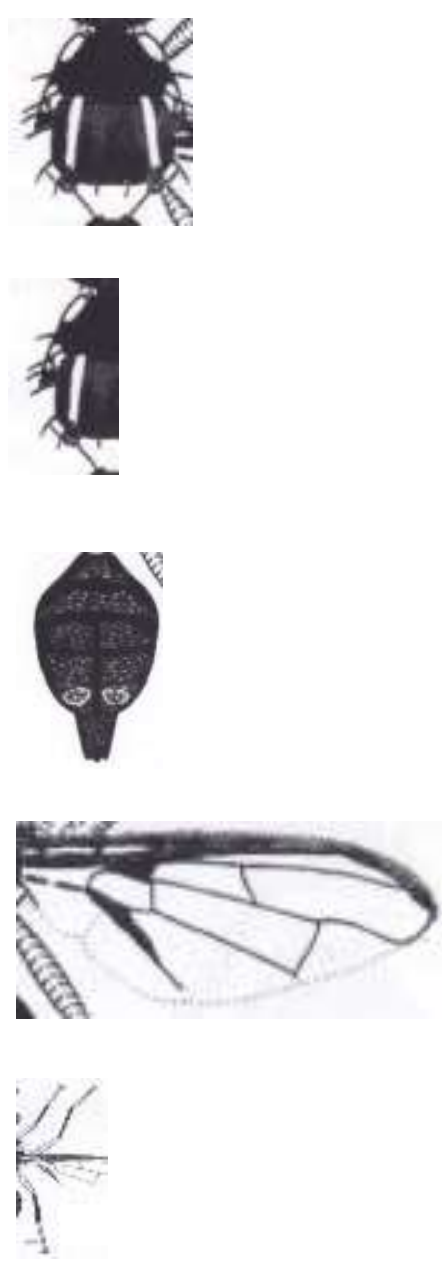

Tibia kaki pertama dan kaki ketiga berwarna gelap sedangkan tibia kaki kedua berwarna kuning.

Adanya pola hitam berupa huruf T, pada abdomen terga ruas III - IV dengan bagian gelap pada lateral yang menyempit, dan ujung pita lateral berbentuk segitiga.

Pita hitam tipis, tepat pada garis tulang R2+3 memiliki pola kosta, dan pola sayap memiliki lebar sedikit melebihi $\mathrm{R} 2+3$.

Caput pada B. carambolae memiliki fasial spot. Ukuran mata pada caput tidak terlalu lebar. 
b. Toraks
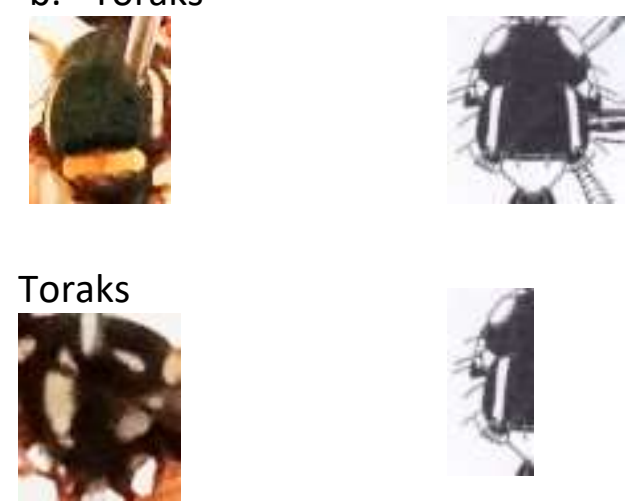

c. Abdomen

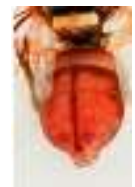

d. Sayap

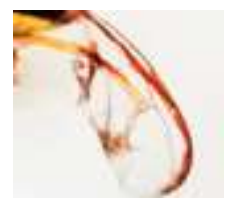

e. Kaki
Lateral presutural tidak ada, medial postsutural tidak ada, adanya lateral postsutural berukuran sedang, skuntum area medial terdapat rambut - rambut halus berwarna keperakan, dan toraks berwarna hitam.

Mesopleural stripe selebar notopleuron.

Pola hitam sempit terdapat pada terga ruas III-V, ceromata terlihat sedikit jelas.

Pola sayap memiliki lebar sedikit melebihi $\mathrm{R} 2+3$ dan

melewati ujung $\mathrm{R} 2+3$ dan $\mathrm{R} 4+5$.

Kaki pertama kedua dan kaki ketiga berwarna gelap.

\section{Kelimpahan Individu}

Kelimpahan individu lalat buah secara umum paling tinggi ditemukan pada perangkap 1,5 $\mathrm{ml}$, lebih tinggi dibandingkan pada perangkap 0,5 $\mathrm{ml}$ dan $1,0 \mathrm{ml}$ tapi berbeda tidak nyata dengan perangkap 2,0 $\mathrm{ml}$ dan $2,5 \mathrm{ml}$. Lalat buah $B$. papayae paling tinggi ditemukan pada perangkap $2,0 \mathrm{ml}$, jumlah ini lebih tinggi dari pada perangkap $0,5 \mathrm{ml}$ dan $1,0 \mathrm{ml}$ tapi tidak berbeda nyata dengan kelimpahan pada perangkap 1,5 ml dan 2,5 ml. Sementara itu, kelimpahan individu $B$. carambolae yang paling tinggi ditemukan pada perangkap 1,5 $\mathrm{ml}$ dan berbeda nyata dengan perlakuan lainnya (Tabel 2).
Jumlah lalat buah $B$. papayae yang terperangkap pada setiap hari pengamatan berfluktuasi. Kelimpahan tertinggi ditemukan pada perangkap 1,5 ml pada hari kedua dan hari ke enam pengamatan. Sementara itu, pada perangkap 2,0 ml, kelimpahan tertinggi terjadi pada hari kedua dan hari kelima pengamatan (Gambar 4).

Jumlah lalat buah $B$. carambolae yang ditemukan setiap hari juga berfluktuasi. Dengan pemberian dosis minyak daun kemangi $1,5 \mathrm{ml}$, kelimpahan tertinggi lalat buah ditemukan pada hari pertama dan hari keenam pengamatan (Gambar 5). 
Tabel 2. Kelimpahan individu lalat buah yang terperangkap dengan pemberian minyak daun kemangi dengan dosis berbeda selama 7 hari pengamatan

\begin{tabular}{|c|c|c|c|}
\hline \multirow{2}{*}{$\begin{array}{l}\text { Dosis minyak daun } \\
\text { kemangi }\end{array}$} & \multicolumn{2}{|c|}{$\begin{array}{l}\text { Lalat buah yang terperangkap } \\
\text { (ekor/perangkap) }\end{array}$} & \multirow[t]{2}{*}{ Total } \\
\hline & B. papayae & B. carambolae & \\
\hline $0,5 \mathrm{ml}$ & 0,67 a & $0,00 \mathrm{a}$ & $0,67 \mathrm{a}$ \\
\hline $1,0 \mathrm{ml}$ & $2,67 a$ & $0,00 \mathrm{a}$ & $2,67 a$ \\
\hline $1,5 \mathrm{ml}$ & $39,33 \mathrm{~b}$ & $1,67 b$ & $41,00 \mathrm{~b}$ \\
\hline $2,0 \mathrm{ml}$ & $40,00 \mathrm{~b}$ & $0,00 \mathrm{a}$ & $40,00 \mathrm{~b}$ \\
\hline $2,5 \mathrm{ml}$ & $32,33 \mathrm{~b}$ & $0,00 \mathrm{a}$ & $32,33 b$ \\
\hline
\end{tabular}

Angka-angka pada lajur yang diikuti oleh huruf kecil yang tidak sama berbeda nyata menurut uji BNT pada taraf $5 \%$ setelah ditransformasikan ke dalam $\sqrt{ } y+0,5$

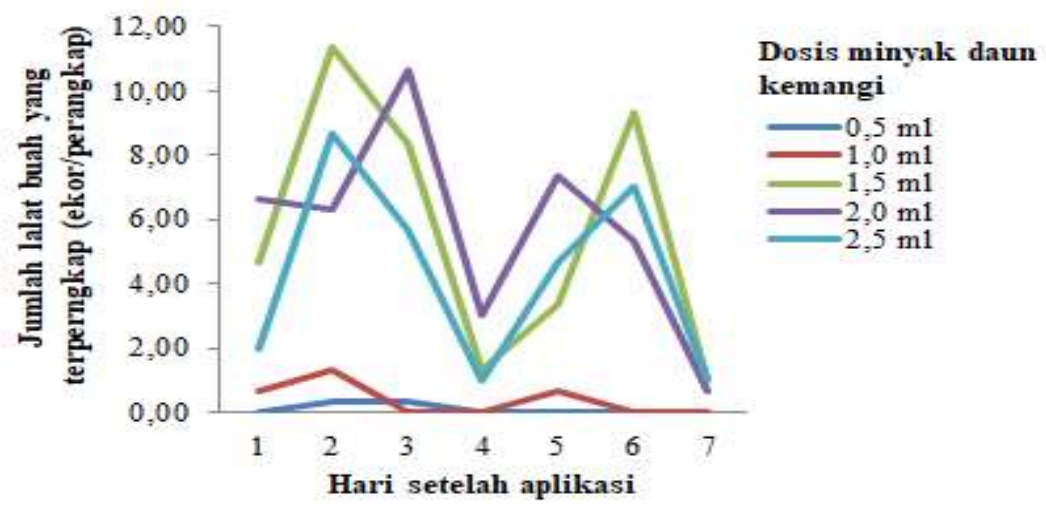

Gambar 4. Fluktuasi lalat buah B. papayae yang terperangkap per 4 jam (06.00-10.00 WIB) selama 7 hari pengamatan pada dosis minyak daun kemangi yang berbeda

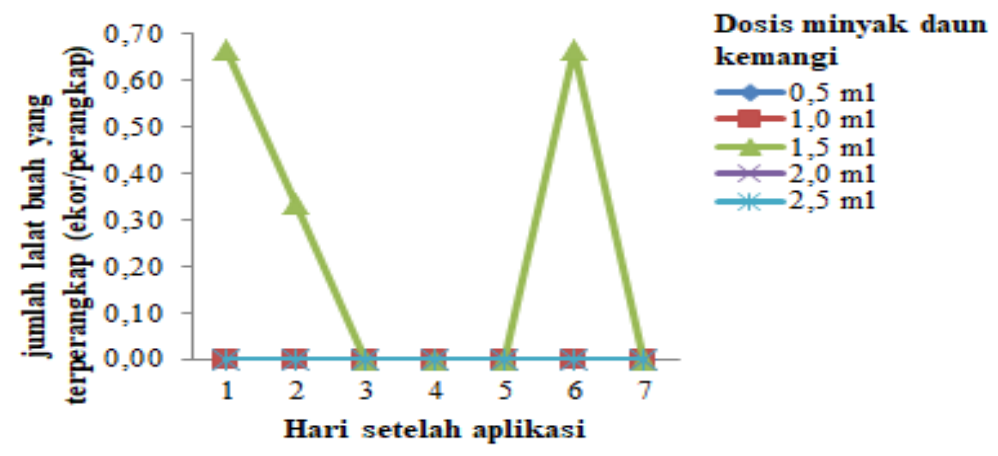

Gambar 5. Fluktuasi lalat buah B. carambolae yang terperangkap per 4 jam (06.00-10.00 WIB) selama 7 hari pada setiap dosis minyak daun kemangi

\section{Sex Ratio}

Ditemukan sebanyak 350 ekor lalat buah yang didominasi oleh $B$. papayae jantan. B. papayae yang masuk ke dalam perangkap yaitu sebanyak 345 ekor, 343 ekor jantan dan 2 ekor betina. B. papayae jantan banyak ditemukan pada perlakuan 1,5 $\mathrm{ml}-2,5 \mathrm{ml}$. Sementara itu B. carambolae yang masuk ke dalam perangkap totalnya sebanyak 5 ekor semuanya adalah lalat buah jantan dan hanya ditemukan pada perlakuan 1,5 ml (Tabel 3). 
Mefta et al. Uji Beberapa Dosis Minyak Daun Kemangi Ocimum basilicum

Tabel 3. Sex ratio lalat buah B. papayae dan B. carambolae

\begin{tabular}{|c|c|c|}
\hline & B. papayae & B. carambolae \\
\hline Dosis minyak daun kemangi & $\begin{array}{c}\text { Jantan : Betina } \\
\text { (ekor/perangkap) }\end{array}$ & $\begin{array}{c}\text { Jantan : Betina } \\
\text { (ekor/perangkap) }\end{array}$ \\
\hline $0,5 \mathrm{ml}$ & $2: 0$ & $0: 0$ \\
\hline $1,0 \mathrm{ml}$ & $8: 0$ & $0: 0$ \\
\hline $1,5 \mathrm{ml}$ & $117: 1$ & $5: 0$ \\
\hline $2,0 \mathrm{ml}$ & $120: 0$ & $0: 0$ \\
\hline $2,5 \mathrm{ml}$ & $96: 1$ & $0: 0$ \\
\hline
\end{tabular}

\section{Suhu dan Kelembaban}

Rerata suhu harian selama satu minggu pengamatan adalah $23^{\circ} \mathrm{C}$, sedangkan rerata kelembaban harian adalah 90,5\%. Suhu harian terendah terjadi pada hari kedua pengamatan, sedangkan suhu harian ter- tinggi terjadi pada hari ke empat pengamatan. Sementara itu, kelembaban terendah terjadi pada hari pertama pengamatan, sedangkan kelembaban tertinggi terjadi pada hari kedua pengamatan (Tabel 4).

Tabel 4. Suhu dan kelembaban harian selama tujuh hari pengamatan, yang diamati setiap pukul 07.00, 13.00 dan 17.00 wib.

\begin{tabular}{|c|c|c|c|c|c|c|c|c|}
\hline \multirow{2}{*}{$\begin{array}{l}\text { Pengamatan } \\
\text { hari ke }\end{array}$} & \multicolumn{3}{|c|}{ Suhu $\left({ }^{\circ} \mathrm{C}\right)$} & \multirow{2}{*}{ Rerata } & \multicolumn{3}{|c|}{ Kelembaban (\%) } & \multirow{2}{*}{ Rerata } \\
\hline & 07.00 & 13.00 & 17.00 & & 07.00 & 13.00 & 17.00 & \\
\hline 1 & 16.4 & 28,3 & 22,2 & 22,3 & 89 & 81 & 87 & 85,7 \\
\hline 2 & 16,5 & 18,7 & 18,5 & 17,9 & 99 & 99 & 99 & 99,0 \\
\hline 3 & 17,7 & 27,9 & 22,4 & 22,7 & 99 & 88 & 87 & 91,3 \\
\hline 4 & 18,5 & 31,9 & 28,2 & 26,2 & 99 & 86 & 85 & 90,0 \\
\hline 5 & 17,9 & 32,7 & 23,3 & 24,6 & 99 & 82 & 89 & 90,0 \\
\hline 6 & 18,7 & 30,2 & 20,2 & 23,0 & 99 & 85 & 88 & 90,7 \\
\hline 7 & 19,1 & 32,2 & 22,2 & 24,5 & 99 & 81 & 81 & 87,0 \\
\hline Rerata & 17,8 & 28,8 & 22,4 & 23,0 & 97,6 & 86,0 & 88,0 & 90,5 \\
\hline
\end{tabular}

\section{PEMBAHASAN}

Berdasarkan hasil penelitian diketahui bahwa tanaman cabai di lokasi penelitian diserang oleh dua jenis lalat buah yaitu B.papayae dan B. carambolae (Tabel 1), yang didominasi oleh B. papayae jantan. Peningkatan dosis minyak daun kemangi tidak diikuti oleh peningkatan jumlah lalat buah yang terperangkap. Kelimpahan individu tertinggi ditemukan pada perlakuan $1,5 \mathrm{ml}$ minyak daun kemangi (Tabel 2). Lalat buah $B$. carambolae tidak begitu tertarik dengan perangkap lalat buah tersebut, kecuali pada perangkap minyak daun kemangi dosis 1,5 $\mathrm{ml}$ (Tabel 3).

Menurut Hasyim et al. (2020), B. papayae dan $B$. carambolae memang tergolong polifag. Lalat buah ini dapat menyerang beraneka ragam buah-buahan seperti pisang, jambu air, nangka, mangga dan pepaya, termasuk cabai. B. papayae merupakan hama yang menyebar paling banyak di Indonesia dengan kisaran inang yang luas. B. papayae memiliki tanaman inang seperti pisang, pepaya, jambu biji, 
jambu nol, jeruk manis, sawo, belimbing, sirsak, manggis rambutan, nangka, cabai, terung, dan lainnya (Ginting, 2009). Tanaman inang dari $B$. carambolae lebih sedikit yaitu belimbing, kluwih, cabai, jambu biji, nangka, mangga, dan almon tropis. Lalat buah $B$. carambolae jantan tertarik metil eugenol (Hasyim et al., 2020).

Lalat buah B. papayae jantan yang terperangkap jauh lebih banyak dari yang betina. Hal ini dikarenakan aroma minyak daun kemangi yang mengandung bahan aktif metil eugenol akan mengeluarkan paraferomon sex sehingga lebih disukai lalat buah jantan. Hal ini sesuai dengan hasil penelitian Susanto et al. (2018), lalat buah jantan sangat tertarik dengan perangkap mengandung atraktan bahan aktif metil eugenol karena memiliki sifat paraferomon. Maesyaroh et al. (2020) melaporkan, senyawa metil eugenol disukai lalat buah jantan sehingga mampu menarik sekitar 30 ekor/perangkap/hari. Menurut Budiyani N K dan I W Sukasana (2020), senyawa metil eugenol merupakan senyawa feromon seks yang disukai lalat buah jantan karena lalat buah betina akan memilih lalat buah jantan yang telah mengkonsumsi senyawa tersebut. Menurut Septiawati (2021), metil eugenol tergolong food lure yaitu lalat buah jantan datang untuk keperluan makan. Lalat buah jantan yang terperangkap lebih banyak juga mempengaruhi proses perkawinan lalat buah. Oktaviani et al. (2015) menyatakan, perkawinan akan semakin sedikit jika banyak lalat buah jantan yang masuk ke dalam perangkap, sehingga populasi lalat buah akan berkurang.

Sementara itu, B. carambolae jantan hanya ditemukan pada perangkap minyak daun kemangi dosis $1,5 \mathrm{ml}$ dengan sex ratio jantan dan betina $5: 0$. Hal ini diduga karena senyawa yang dihasilkan oleh minyak daun kemangi tidak disukai oleh B. carambolae. Lalat buah $B$. carambolae hanya singgah dan masuk pada perangkap dosis $1,5 \mathrm{ml}$. Hasyim et al. (2020), menyatakan, jika buah yang terserang dan jatuh ke bawah pohon banyak maka lalat buah berpotensi untuk singgah di buah yang terserang tersebut.

Perlakuan perangkap menggunakan minyak daun kemangi dengan dosis $1,5 \mathrm{ml}$ cenderung lebih menarik lalat buah untuk datang dibandingkan dosis lainnya. Hal ini sama halnya dengan hasil penelitian Yuniastuti (2015) bahwa dosis minyak selasih yang efektif digunakan untuk memikat lalat buah yaitu dosis $1,5 \mathrm{ml}$.

Suhu dan kelembaban saat penelitian dilakukan diduga mempengaruhi kehadiran lalat buah di lahan cabai. Pada hari kedua suhu di sekitaran area pertanaman cabai rendah yaitu $17,9^{\circ} \mathrm{C}$, sehingga proses penguapan terjadi lebih lambat. Pada hari kedua, lalat buah yang paling banyak pada perangkap minyak daun kemangi dosis 1,5 ml (11,33 ekor). Hal ini sesuai dengan penelitian Susanto et al. (2017), bahwa lalat buah paling banyak masuk perangkap pada suhu $\leq 20^{\circ} \mathrm{C}$ dan paling sedikit pada suhu $>20^{\circ} \mathrm{C}$.

Pada hari keempat, jumlah B. papayae yang terperangkap pada setiap dosis minyak daun kemangi mengalami penurunan. Hal ini diduga karena suhu di area pertanaman cabai meningkat mencapai $26,2^{\circ} \mathrm{C}$ dan kelembaban turun menjadi $90 \%$, sehingga proses penguapan senyawa metil eugenol terjadi lebih cepat. Menurut Sahetapy et al. (2019), faktor iklim seperti suhu dan kelembaban sangat mempengaruhi populasi lalat buah. Hasyim et al. (2020) menyatakan, kelembaban mempengaruhi populasi lalat buah. Kelimpahan lalat buah tinggi ketika kelembapan tinggi, sedangkan pada kelem- 
baban rendah terjadi peningkatan mortalitas imago yang baru keluar dari pupa.

Pada hari ketujuh pengamatan, jumlah B. papayae yang terperangkap mengalami penurunan. Diduga karena kandungan bahan aktif metil eugenol yang ada pada minyak daun kemangi mulai melemah seiring dengan penguapan yang terjadi selama tujuh hari. Menurut Effendy et al. (2010), senyawa metil eugenol akan berkurang setiap harinya dikarenakan terjadinya penguapan.

\section{KESIMPULAN}

Ada dua spesies lalat buah yang ditemukan di sekitar tanaman cabai yaitu Bactrocera papayae dan Bactrocera carambolae, yang didominasi oleh $B$. papayae jantan. Perangkap yang mengandung 1,5 ml minyak daun kemangi paling tinggi menarik kehadiran lalat buah tersebut. Sanitasi lahan sangat berpengaruh terhadap kelimpahan individu lalat buah.

\section{DAFTAR PUSTAKA}

Anugraheni DD. 2018. Pengaruh insektisida nabati ekstrak tanaman kemangi (Ocimum basilicum) dan daun sirih terhadap mortalitas lalat buah (Bactrocera sp.). [Skripsi]. Universitas Muhammadiyah Surakarta.

Arief. 2009. Budidaya tanaman sayuran. Institut Pertanian Bogor. Bogor.

Arif A. 2015. Pengaruh bahan kimia terhadap penggunaan pestisida lingkungan. Jf Fik Uinam, 3(4), 134-143.

Badan Pusat Statistik. 2019. Produktivitas cabai besar menurut Provinsi, tahun 2015-2019. Direktorat Jenderal Hortikultura, Kementrian Pertanian. Jakarta.

BPS RI. 2019. Distribusi perdagangan komoditas cabai merah Indonesia tahun 2019. Jakarta

Budiyani NK dan IW Sukasana. 2020. Pengendalian serangan hama lalat buah pada intensitas kerusakan buah cabai rawit (Capsicum frutencens $L$ ) dengan bahan petrogrnol. Jurnal Agrica. 13(1).

Effendy T, R Rani, dan S Samad. 2010 Pengujian beberapa jenis tanaman sebagai sumber atraktan lalat buah (Bactrocera spp.) (Diptera:Tephritidae) pada tanaman cabai (Capsicum annuum L). Prosiding Seminar Nasional.

Ginting R. 2009. Keanekaragaman lalat buah (Diptera: Tephritidae) di Jakarta, Depok, dan Bogor sebagai bahan kajian penyusunan analisis resiko hama. [Thesis]. Institut Pertanian Bogor.

Hasyim A, L Lukman, dan W Setiawati. 2020. Teknologi pengendalian hama lalat buah. IAARD Press. Jakarta.

Hotimah H, Purwatiningsih, dan K Senjarini. 2017. Deskripsi morfologi Drosophilla melanogaster normal (Diptera: Drosophilidae), strain sepia dan plum. Jurnal Ilmu Dasar. 18(1).

Kardinan A. 2019. Prospek insektisida nabati berbahan aktif metil eugenol $\left(\mathrm{C}_{12} \mathrm{H}_{24} \mathrm{O}_{2}\right)$ sebagai pengendali hama lalat buah Bactrocera spp (Diptera:Tephritidae). Jurnal Perspektif 18(1), 16-17.

Ketaren S. 1985. Pengantar teknologi minyak atsiri. Balai Pustaka. Malang.

Maesyaroh SS, J Mutakin, FA Sopandi, dan TN Arifah. 2020. Pengaruh berbagai dosis atraktan terhadap efektivitas perang-kap botol lalat buah pada tanaman jeruk (Citrus sp.). Prosiding Seminar Nasional

Muryati, A Hasyim, dan WD Kogel. 2007. Distribusi spesies lalat buah di Sumatera Barat dan Riau. Jurnal Hortikultura 17(1): 61-68.

Oktaviani NE, A Sutikno, dan D Salbiah. 2015. Uji kemampuan beberapa konsentrasi ekstrak daun selasih ungu (Ocimum sanctum L.) sebagai atraktan hama lalat 
buah pada pertanaman jambu biji (Psidium guajava L.). Jurnal online mahasiswa Faperta 2(2).

Sahetapy B, MR Uluputty, dan L Naibu. 2019. Identifikasi lalat buah Bactrocera spp.) asal tanaman cabai (Capsicum annuum L) dan belimbing (Averrhoa carambola) di Kecamatan Salahutu Kabupaten Maluku Tengah. Jurnal Agrikultura 30(2): 63-74.

Salbiah D, A Sutikno, dan A Rangkuti. 2013. Uji beberapa minyak atsiri sebagai atraktan lalat buah pada tanaman cabai merah (Capsicum annuum L.). Jurnal Agroteknologi 4(1): 1

Septiawati D. 2021. Jenis dan populasi lalat buah (Diptera:Tephritidae) yang menyerang tanaman cabai di Kota Padang. [Skripsi]. Universitas Andalas.

Siwi S S, P Hidayat, dan Suputa. 2006. Taksonomi dan bioekologi lalat buah penting di Indonesia. BB-Biogen.

Suputa, Cahyaniati, A Kustaryati, M Railan, Issusilaningtyas, dan WP Mardiasih. 2006. Pedoman identifikasi hama lalat buah. Direktorat Perlindungan Tanaman Hortikultura. Jakarta.

Susanto A, Y Supriyadi, Tohidin, N Susniahti, dan V Hafizh. 2017. Fluktuasi populasi lalat buah Bactrocera sp. (Diptera:
Tephritidae) pada pertanaman cabai merah (Capsicum annuum) di Kabupaten Bandung, Jawa Barat. Jurnal Agrikultura, 28(3): 141-150.

Susanto A, WD Natawigena, LT Puspasari, dan NIN Atami. 2018. Pengaruh penambahan beberapa esens buah pada perangkap metil eugenol terhadap ketertarikan lalat buah Bactrocera dorsalis kompleks pada pertanaman mangga di Desa Pasirmuncang, Majalengka. Jurnal Perlindungan Tanaman Indonesia 22(2)

Syukur M, R Yunianti, dan R Dermawan. 2018. Budidaya cabai panen setiap hari. Penebar Swadaya. Jakarta.

Trihutanti IW. 2018. Efektivitas insektisida alami ekstrak tanaman kemangi (Ocimum basilicum) dan ekstrak daun mimba sebagai pengendalian lalat buah (Bactrocera sp.). [Skripsi]. Universitas Muhammadiyah Surakarta.

Yuniastuti S. 2015. Pemanfaatan selasih sebagai pemikat lalat buah pada tanaman sayur dan buah di Jawa Timur. Balai Pengkajian Teknologi Pertanian. Jawa Timur. 